\title{
Descriptive study of job satisfaction and job dissatisfaction in a sample of Croatian seafarers
}

\author{
Ana Slišković, Zvjezdan Penezić
}

Department of Psychology, University of Zadar, Zadar, Croatia

\begin{abstract}
Background: Given the general lack of studies on well-being in Croatian seafarers, the aim of this study was to determine the level and sources of their job satisfaction and job dissatisfaction.

Materials and methods: This descriptive study was conducted on a sample of Croatian seafarers ( $n=530)$, employed in various functions on cargo ships. Using an online survey, we examined overall job satisfaction, and satisfaction with some specific aspects of work. Participants additionally responded to two open questions relating to the sources of their job satisfaction and job dissatisfaction, and these data were analysed using a qualitative approach.

Results and conclusions: The results showed a moderate level of overall job satisfaction, while analysis of the 10 specific facets indicated that the participants are, on average, most satisfied with payment, and least satisfied with the achieved benefits and work organisation on board. The results of the qualitative analysis showed that among the main sources of job satisfaction are: financial stability and security, the ratio of work days to days off, and the quality of days off, and the nature and dynamics of the work. On the other hand, sources of dissatisfaction relate primarily to: separation from home and family, the status of Croatian seafarers in the Republic of Croatia, and working and living conditions on board.
\end{abstract}

(Int Marit Health 2015; 66, 2: 97-105)

\section{Key words: Croatian seafarers, well-being, job satisfaction, job dissatisfaction}

\section{INTRODUCTION}

Despite advances in the modern maritime sector, such as improvements in safety standards, shorter contract duration on board, and technological progress which allows better communication with families, seafaring is still highly demanding, stressful and a high-risk occupation [1, 2]. Previous studies have identified a large number of stressors and risks faced by seafarers, such as long periods away from home, isolation, long working hours, lack of shore leave, fatigue, high levels of work-related stress, accidents and maritime disasters, exposure to hazardous substances, communicable diseases, impaired treatment options for cardiovascular diseases, and dangers from piracy [1-5]. These can lead to consequences for the physical health and psychological well-being of seafarers. The need for serious focus on occupational stressors and risks in seafarers is evident from mortality studies in the seafaring population [6-12], which show that causes of mortality in seafarers can be divided into three categories: 1) mortality from accidents, 2) mortality from diseases related to lifestyle, and 3) mortality from suicide. The data on suicides proves that the mental health of seafarers in many cases continues to be very poor and often fatal [4]. Still, most studies on seafarers have focused on physical health and lifestyle risk factors, while mental health and psychological well-being in seafarers are less studied [5], especially in Croatian samples. Despite the maritime orientation of a country with about 22,000 seafarers in national and international/deep sea shipping [13], well-being in Croatian seafarers is almost completely neglected.

In this research we focused on job satisfaction as an important aspect of well-being. Job satisfaction can be 
defined as "a pleasurable or positive emotional state resulting from appraisal of one's job or job experiences" [14]. Previous studies on the working population show that job satisfaction is negatively associated with occupational stress and positively with health [15]. Besides being an indicator of worker well-being and health, job satisfaction is also important from an organisational perspective, since it is associated with job performance, turnover and withdrawal behaviour [16].

The few previous studies on job satisfaction in seafarers show that job satisfaction is a significant predictor of life satisfaction [17], which correlates with physical and psychosocial factors in the work environment [18]. Since cultural and contextual differences may have important implications for the health and well-being of seafarers $[5,18,19]$, we carried out this research on a Croatian sample of seafarers. The main aim of this study was to identify the level and sources of job satisfaction and job dissatisfaction in Croatian seafarers employed on cargo ships.

\section{MATERIALS AND METHODS}

\section{PARTICIPANTS}

The study included 530 Croatian seafarers employed on cargo ships. The largest number of participants work on liquefied natural gas (LNG) and liquefied petroleum gas (LPG) ships (27.1\%), oil tankers and oil products (17.3\%), and containers (17.1\%), while the remainder of the sample work on ships for the transportation of chemicals, bulk cargo, cargo on wheels, general cargo and other cargo ships. The ships on which the participants are employed are predominantly owned by foreign shipping organisations (92.7\%), and only about $7 \%$ of the participants were employed on Croatian cargo ships.

The average age of participants was $37.7 \pm 9.5$ years, their total years of service $14.5 \pm 9.6$ years, and length of service in the maritime sector $13.5 \pm 9.4$ years.

The study included employees in various positions on board, and in the most part (85.5\%) represented by officers, chief engineers and commanders. More specifically, the study included deck officers (36.7\%), engine officers $(22.8 \%)$, commanders (16.4\%), chief engineers (9.6\%), electricians (6.6\%), trainees (3.2\%) and crew deck, engine room and white staff $(<5 \%)$.

Most participants are married (66.7\%), followed by unmarried (21.8\%), in domestic partnership (9.2\%), divorced $(1.7 \%)$ and widowed $(0.6 \%)$. About two-thirds of the participants (63.2\%) have children.

\section{MATERIALS}

The first part of the questionnaire included questions about the socio-demographic and working characteristics of the subjects (years of service, type of cargo ship, profession/work position on board, marital status, children, and current location).

The study used a scale of overall job satisfaction [20], consisting of 5 statements to which participants expressed their agreement on a scale from 1 to 5 ( 1 = strongly disagree; 5 = strongly agree).

Participants further evaluated their levels of satisfaction with 10 specific aspects of the job, selected on the basis of earlier literature. The following aspects were used: salary, realisation of benefits, working conditions on board, organisation of work on board, organisation of work in the company, superiors, opportunities for spending leisure time on board, food, interpersonal relations on board, and progression opportunities. Satisfaction with each of the aspects was evaluated on a scale from 1 to 5 ( 1 = not at all satisfied; 5 = completely satisfied).

Participants additionally responded to two open questions relating to the sources of their job satisfaction and job dissatisfaction ("With respect to your job as a seafarer, please specify what makes you particularly satisfied/dissatisfied").

\section{METHODS}

The study was conducted in 2014 using an online survey. Requests for help in advertising the study and invitations to participate in the study were sent via electronic mail to Croatian shipping companies, Croatian agencies for seafarers, the Seafarers Union of Croatia, education institutions in Croatia involved in the training of seafarers, the web page 'Pomorac.net', which is popular among Croatian seafarers, Linkedln groups of Croatian seafarers, and some individuals. Therefore, a snowball strategy of sampling was used. At the time of the survey, $39 \%$ of participants were on board, and $61 \%$ at home. Due to the non-probabilistic sampling procedure used and the lack of a population frame for 'Croatian seafarers on cargo ships', it is impossible to give data on the response rate in relation to the target population or the representativeness of the sample. However, on the basis of the national statistics data (official statistics of seafarers in international shipping, by Ministry of Maritime Affairs, Transport and Infrastructure) which indicate 15,184 Croatian seafarers in international/deep sea shipping (including foreign and national ships) for 2014, it can be said that our data is obtained on $3.5 \%$ of population of Croatian Seafarers in International Shipping (CSIS). Comparisons of ranks and profession within sample with official statistics show that higher ranks are overrepresented in our sample. To be more precise, sample consisted of $16.4 \%$ commanders (vs. $10.5 \%$ of CSIS), $9.6 \%$ chief engineers (vs. $8.8 \%$ of CSIS), $36.7 \%$ engine officers (vs. $21.1 \%$ of CSIS) and $22.8 \%$ of engine officers (vs. $17.6 \%$ of CSIS). However, it should be 
Table 1. Sources of job satisfaction

\begin{tabular}{|c|c|}
\hline $\begin{array}{l}\text { Sources of job satisfaction } \\
\text { (\% of responses)* }\end{array}$ & Examples of responses \\
\hline $\begin{array}{l}\text { 1) Financial stability and security } \\
(52.1 \%)\end{array}$ & $\begin{array}{l}\text { "The only thing I am satisfied with in this job is payment, which is high compared to the current } \\
\text { situation in the country, but of course that means that I have to be absent from home half a year } \\
\text { to secure an existence for my family." } \\
\text { "The money and, in part, security of new employment in the case of job loss due to market } \\
\text { demands." }\end{array}$ \\
\hline $\begin{array}{l}\text { 2) Ratio between working and vaca- } \\
\text { tion days, and quality of days off } \\
(21.3 \%)\end{array}$ & $\begin{array}{l}\text { "Equal length of annual vacation and stay on board." } \\
\text { "Free time that I have at home. I would never have that if I were working in some company at } \\
\text { home." }\end{array}$ \\
\hline $\begin{array}{l}\text { 3) Nature and dynamic of job } \\
\text { (15.1\%) }\end{array}$ & $\begin{array}{l}\text { "Great challenge and responsibility that are put in front of me, and satisfaction after each } \\
\text { successfully completed contract." } \\
\text { "I am satisfied with my job because I do engineering work that I love." }\end{array}$ \\
\hline $\begin{array}{l}\text { 4) Job in international working mar- } \\
\text { ket and promotion opportunities in } \\
\text { compliance with abilities } \\
(6.8 \%)\end{array}$ & $\begin{array}{l}\text { “...Internationally open labour market, international work environment, high standards of work } \\
\text { ethics, high technical standards, regular training and adoption of the latest technology, open } \\
\text { possibilities of progress related to dedication and knowledge..." } \\
\text { "...that l'm not working in Croatia and I am not dependent on its politicians." }\end{array}$ \\
\hline $\begin{array}{l}\text { 5) Company and living and working } \\
\text { conditions on board } \\
(11.7 \%)\end{array}$ & $\begin{array}{l}\text { "The Company - I work hard, but my company has given me everything I could wish for in the job, } \\
\text { and of course it has provided a comfortable life for my family (not the state and government)." } \\
\text { "Given access to the Internet and communication with the family, opportunities for sports } \\
\text { activities." }\end{array}$ \\
\hline $\begin{array}{l}\text { 6) Interpersonal relationships } \\
\text { on board } \\
(6.4 \%)\end{array}$ & $\begin{array}{l}\text { "...lf you're lucky, you're on board with healthy people who value teamwork and a company which } \\
\text { takes reasonable care of its people... in such conditions impossible tasks are executed. But such } \\
\text { examples are rare... very rare." } \\
\text { "....with some workaholic, smiling people, because of whom this job sometimes looks easier and } \\
\text { more relaxed." }\end{array}$ \\
\hline $\begin{array}{l}\text { 7) Travelling and learning about } \\
\text { other cultures } \\
(6.6 \%)\end{array}$ & $\begin{array}{l}\text { "See a little bit of the world." } \\
\text { "Broadening of perspective due to learning about new cultures." }\end{array}$ \\
\hline
\end{tabular}

*Percentages of responses are calculated as ' $n$ ' of responses in each category divided by ' $N$ ' of subjects (530), but the fact that some subjects cited two or more sources of job satisfaction must be taken into the account.

noted that these comparisons should be considered with caution since our target population was Croatian seafarers in international cargo shipping, and not total CSIS, which also includes seafarers in international passenger shipping. Finally, regarding the type of cargo ship, comparisons with available data of Croatian maritime market, presented by M. Zorovic at $16^{\text {th }}$ European Manning and Training Conference, show that our sample is overrepresented by seafarers employed on LNG and LPG ships and underrepresented by those employed at tankers. Namely, data show that Croatian seafarers international shipping in 2012 were employed at tankers (45\%), dry cargo ships (20\%), LNG (15\%), offshore (10\%) and passenger ships (10\%). These comparisons are also only approximate, not only because of difference in population frame, but also because somewhat different categorisations of types of ships, as well as because of seafarers' fluctuations within period of 2 years.

\section{ANALYSIS}

Average levels of overall job satisfaction and satisfaction with 10 specific job aspects (mean and standard deviation) as well as percentages of participants expressing different levels of overall job satisfaction at 5-point scale were calculated. Average level of overall job satisfaction was calculated as total score divided to number of items. Average levels of satisfaction with 10 specific job aspects were compared using ANOVA and post-hoc Scheffé test. The responses to the open-ended questions were analysed using thematic analysis, and constructed categories of sources of satisfaction and dissatisfaction, together with examples of typical responses, are shown in Tables 1 and 2. Although the primary objective of this analysis was to provide deeper insight into the reasons for (dis)satisfaction, for each of the sources of satisfaction/ /dissatisfaction, data on percentages is also given.

\section{RESULTS}

Regarding overall job satisfaction, on average, participants were moderately satisfied (3.35 \pm 0.89 on 5 -point scale, $7.2 \%$ of $1=$ highly dissatisfied, $17.5 \%$ of $2=$ dissatisfied, $43.2 \%$ of $3=$ moderately (dis)satisfied, $27.6 \%$ of $4=$ satisfied, and $1.7 \%$ of $5=$ highly satisfied).

The results of ANOVA $(F(9.4770)=47.16, p<0.001)$ on the ten specific aspects of satisfaction (Fig. 1) indicate that the participants are, on average, most satisfied with 
Table 2. Sources of job dissatisfaction

\begin{tabular}{|c|c|}
\hline $\begin{array}{l}\text { Sources of job dissatisfaction } \\
\text { (\% of responses)* }\end{array}$ & Examples of responses \\
\hline $\begin{array}{l}\text { 1) Separation from home and family } \\
(20.9 \%)\end{array}$ & $\begin{array}{l}\text { "I miss being with the family, Internet helps, but does not solve the closeness with them." } \\
\text { "...always missing family moments while children are growing up, which no one can replace." }\end{array}$ \\
\hline $\begin{array}{l}\text { 2) Status of seafarers in the } \\
\text { Republic of Croatia } \\
(22.8 \%)\end{array}$ & $\begin{array}{l}\text { "Well, generally most unhappy at the treatment of seafarers in our country, i.e. they require all } \\
\text { sorts of things, and in return nothing... First of all, paying taxes needs to be abolished immediately } \\
\text { because the state does not give anything i.e. only demands, or if they want us to pay them they in } \\
\text { turn should give something..." } \\
\text { "Neglect, from the state, of seafarers and their benefits. We cannot be in the same group as } \\
\text { others for retirement, since no one will find work in the profession to the age of } 67 . " \\
\text { "The payment of health insurance in the Republic of Croatia during stays on board (at that time } \\
\text { I already have health insurance through the company I work for, and my whole family)." }\end{array}$ \\
\hline
\end{tabular}

3) Status of Croatian seafarers in the international labour market $(2.8 \%)$

4) Status of seafarers in the company and promotion opportunities $(7.3 \%)$

5) Company and living and working conditions on board

(35.8\%)

6) Interpersonal relationships on board

(12.8\%)

7) Changes in maritime sector $(12.8 \%)$
"Underpayment in comparison to other nations."

"As a Croat it is hard to make progress in the offshore sector, for example. We can talk about what we want, but our passports are of no significance outside. Cheap labour will smash us."

"Slave-holding treatment by the company of its people."

"The fact that the work is not valued as it should be, people are being promoted by luck, because decisions about the progress of the people are made in the office of the company, not on board, where people know how one works, while the real evaluation of individual work is difficult to convey in paper reports to the people in the office."

"Non-respect of the contract, contract duration of four months on board converts to five months, sometimes even longer."

“Daily work 12-14 hours, after three months' stay I think we need a psychiatrist before coming home, because the only topic of my life is work."

"Isolation. Today LNG ships are floating prisons."

"The inability to use the Internet on board."

"...in most companies food is criminally bad and poor quality, and even worse is the preparation. In addition to that, the menu is always adjusted for Asians, who are more prevalent on board, and the cook is Asian."

"Relationships that are sometimes negative and from which there is no escape."

"Sometimes superiors are not correct towards the lower-ranking staff."

"The industry is moving in a direction that increases the number of tasks we perform, and which are not directly related to navigation. Autonomy of crew (especially officers) is decreasing, increasing administration..."

"...capitalism that is relentless, and it is almost impossible to do the job by the book, i.e. to harmonize the rules imposed or required by the STCW, ISM and others."

*Percentages of responses are calculated as ' $n$ ' of responses in each category divided by 'N' of subjects (530), but the fact that some subjects cited two or more sources of job dissatisfaction must be taken into the account.

salary and least satisfied with the realisation of benefits and organisation of work on board. A post-hoc Scheffé test confirmed the significant difference between these aspects and the others.

\section{SOURCES OF JOB SATISFACTION (TABLE 1)}

Over half of the participants stated financial stability and security as a source of satisfaction. Many of them state income as the only source of pleasure related to the job, and the primary reason for being in this job, while in others income is one of the important sources of satisfaction. Besides satisfaction with the level of income, also emphasized are security of regular income, relative job security and relative security in this occupation despite the crisis.
In addition to financial status and security, the most commonly cited sources of satisfaction are holidays, amount of annual leave, days off, or the ratio between work and days off, especially in favourable contract types (e.g. 3 on, 3 off). In describing this source of satisfaction many seafarers point out the opportunity of dedicating themselves to quality family life during days off.

Many seafarers noted the nature and dynamic of the job as a source of satisfaction. Satisfaction with the work itself is further described and explained by the fact that they are doing work that they love, that is interesting, challenging and responsible, for which they were educated, and which they think they are doing well.

An additional source of satisfaction may be described as work in a highly competitive international working environment 


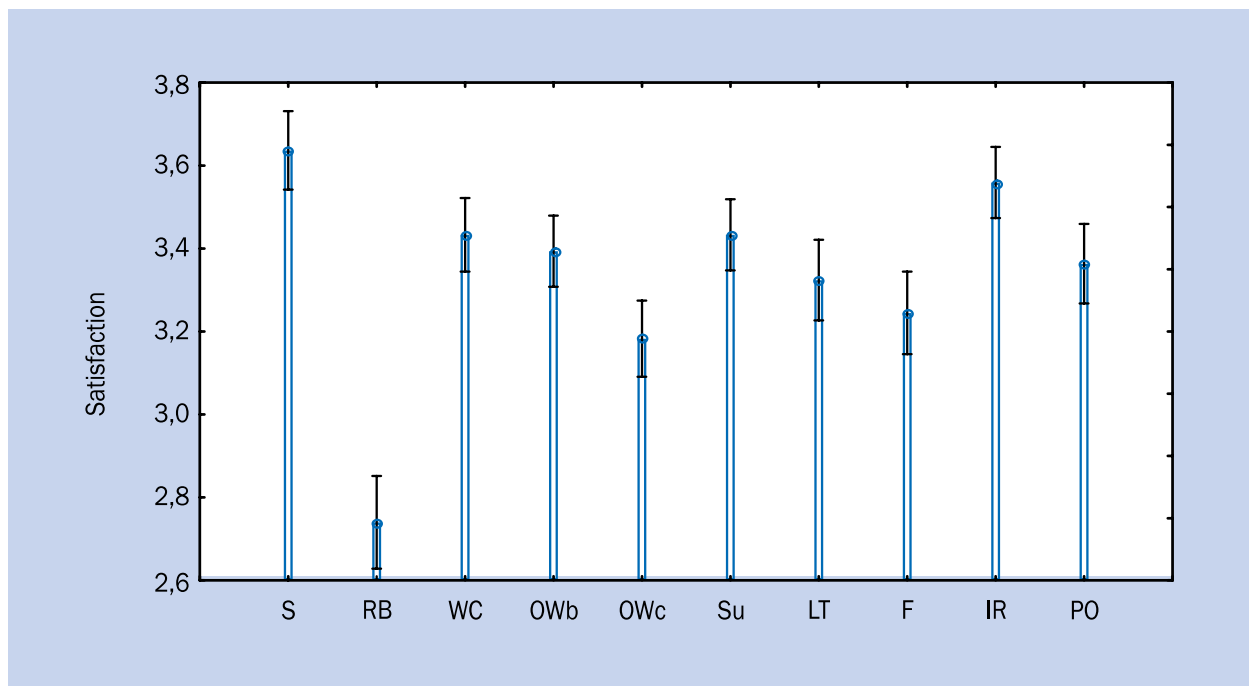

Figure 1. Level of satisfaction with specific job aspects $(n=530) ; S$ - salary; RB - realisation of benefits; WC - working conditions on board; $\mathrm{OWb}$ - organisation of work on board; OWc - organisation of work in the company; Su - superiors; LT - opportunities for spending leisure time on board; F - food; IR - interpersonal relations on board; PO - progression opportunities

dominated by high standards of work ethics. It emphasizes advancement according to abilities, and huge differences in relation to living and working in the Republic of Croatia.

Level of income, length of stay on board, and working conditions on board are very dependent on the company, and some seafarers listed company as a special source of satisfaction. With respect to the company, satisfaction relates to the following items: a favourable contract, equal treatment by the company, good company management of the business, paid training by companies and investment in training, satisfaction with the introduction of changes on the basis of the idea of listening to employees of the company, appropriate selection of personnel, appropriate organisation of work, adequate security system and awareness of on-board safety, respect for working hours and payment for additional hours of work. Regarding living and working conditions on board, participants emphasized their satisfaction with access to free internet on board, and they commonly note this as one of "the rare sources of satisfaction on board". In addition, some participants noted satisfaction with the conditions for sports and recreational activities on board, base of literature on board, the existence of a budget for a comfortable life on board, opportunities for shore leave, and having food cooked by a Croatian chef on board.

Although colleagues on board are sometimes described in bad terms, recognition of the importance of positive relationships with colleagues and superiors on board is clearly evident in responses. This can be described by the following example: "Whether I enjoy the job or not depends on who is with me on board". In addition to colleagues, relationships with superiors are particularly emphasized, and especially the willingness of the superior for teaching.
While shore leave is much rarer in modern maritime life than in former times, some seafarers cite travel to foreign cities as a source of satisfaction. Besides the pleasures of travelling, a general broadening of horizons from working in an international environment and learning about other cultures is also emphasized.

\section{SOURCES OF JOB DISSATISFACTION (TABLE 2)}

In line with expectations, one of the most common sources of dissatisfaction that participants cite is separation from home and family. This source of dissatisfaction is often in first place among those cited, and it is especially pronounced in unfavourable contracts and irregular shift rotation. Dissatisfaction with the separation of lifestyles often 'overlaps' with the financial pressures that individuals feel and dissatisfaction over the state system of taxation.

Many participants note that they are dissatisfied with their status. Responses relating to unfavourable status and treatment divide into 3 categories: status in the country, status in the international market and status in the company they work for.

Regarding seafarers' status in the state, it can be said in general that many participants are dissatisfied with state laws governing their rights and obligations. Dissatisfaction regarding system of education and training is expressed in terms of the legislation relating to certificates of qualification, and also to the organisation and implementation of training and instruction. Since seafarers who are on board more than 183 days a year are exempted from paying taxes, participants feel strong pressure of taxes if they do not meet that criterion, since they often do not have that 
under their own control. Regarding the pension system, participants are specially dissatisfied by the raising of the threshold for going into retirement at the state level, and by the lack of occupational benefits for length of service (i.e. lack of accelerated retirement). Furthermore, participants expressed their dissatisfaction with the obligation to pay health insurance on an annual basis, since they spend at least half of the year on board. Their dissatisfaction further relates to bureaucracy in the Republic of Croatia, to the slow pace of resolving administrative matters in the public services, to a lack of understanding and support from the staff at the ministry in charge and port authorities. Finally, participants also expressed dissatisfaction with those from whom they expect support and the protection of their rights (agencies and union).

Most of the participants work for foreign companies, and some of them see their status in the international market as unfavourable. For them, dissatisfaction arises from disadvantageous comparisons to other nations particularly in relation to differences in wages. Further, some participants feel discriminated against on grounds of nationality with respect to the possibility of promotion. Finally, there is also apparent fear that stems from insecurity of employment and advancement because of the increasing amount of cheaper labour in the international maritime sector.

Some participants expressed dissatisfaction with their status in the company. They note that progress and promotion within the company is difficult and slow.

Living and working conditions on board vary from company to company, and greatly depend on the company-ship relation. Dissatisfaction with working conditions can be classified under the following aspects: contract, workload and overtime hours, isolation, wages, availability and price of the Internet, poor quality of food, opportunities for social and sports activities on board, and non-compliance with safety standards. Dissatisfaction with the contract is derived from the length of time on board and from an unfavourable ratio of work to days off. Furthermore, non-compliance with contract regarding staying on board and at home is also noted, even among those who have favourable contracts in terms of the ratio between work and days off. Breach of contract and irregularity of shifts markedly violate leisure time at home, disable quality rest and family and social obligations, and also negatively affect financial planning. One source of dissatisfaction certainly relates to the workload on the ship, which is particularly evident in the number of hours over the norm, which is not in accordance with the rules and not adequately paid. Isolation is one of the most commonly cited stressors in seafaring and, not surprisingly, is here also shown as one of the sources of discontent. Living and working in such an isolated environment is somewhat offset by financial income compared to average Croatian wages.
Further, the availability and price of the Internet is often a source of dissatisfaction. Complaints about food on board are also very common. The importance of the food issue can be read from the fact that in many responses the food is the only source of dissatisfaction on board. Participants complain about quality of food, inadequate impact of food on board on health, and cultural misfit of food since the cook is often from another culture. Complaints are also given regarding the absence of facilities for social and sports activities. Dissatisfaction also stems from safety issues, especially where the necessary level of attention is not devoted to safety standards, and on older ships that are not adequately maintained.

Poor interpersonal relationships on board are a common source of dissatisfaction. Poor interpersonal relationships on board are a stronger stressor in comparison to a job on land, which is best described in the response "you cannot escape from them". Relationships with superiors and serious fear of losing the job because of problematic relations with superiors are also emphasized. Some participants point out social problems on an ethnic basis. Finally, answers in this category also highlighted generalising and stereotypes on a national/ethnic basis.

Some of the participants stated changes in the maritime sector as a reason for major dissatisfaction. The changes described are reflected in an increase in the administrative part of the job, which increases overall workload, as well as compliance with various laws, rules and standards, which leads to conflict of work role. Also, in spite of efforts towards improving working conditions in the maritime sector, many cite the deteriorating quality of working conditions. Furthermore, participants cite a decline in the quality of seafarers (cheaper labour) as a frequent source of dissatisfaction, because it makes work more difficult, and also makes the job unsafe. In general, work in the modern maritime sector is described as being more stressful and demanding in comparison to former times.

\section{DISCUSSION}

Obtained results showed in average moderate level of job satisfaction which is similar to the levels on other working populations obtained with the use of same scale (e.g. [21]). On the other hand, percentages of satisfied and highly satisfied seafarers are lower compared to workers from European Union countries [22], although the use of different scales has to be taken into account (5-point vs. 4-point scale). However, the objective of this study was more related to the levels of satisfaction by particular aspects of jobs which would be more related to the seafaring occupation. Since job satisfaction has not yet been investigated in Croatian seafarers, great emphasis was also placed on qualitative analysis of open responses on their sources 
of job satisfaction and dissatisfaction. Overall results of quantitative and qualitative analysis of the results of the study showed that the dissatisfactions of the tested sample relate mainly to the organisation of work and working and living conditions on board, non-realisation of benefits or the adverse status of seafarers in Croatia, and separation from home and family. On the other hand, the satisfactions of the Croatian sample relate mainly to financial security, free time at home, and the nature and dynamic of the work. While some of the sources of dissatisfaction obtained - for example, separation, isolation, working conditions - are recognised in the maritime sector as typical occupational stressors [1-5], the obtained results show some national specificities. Obviously, dissatisfaction with the status and treatment of seafarers in the country are factors that further impair the well-being of Croatian seafarers and which the ministry in charge should take into consideration.

Regarding the theoretical contributions of the study results, it is possible to ask a question about the relevance of Herzberg's two-factor theory from the 60s [23] to mariners in Croatia today. According to Herzberg, behaviour in companies falls under the influence of two independent groups of factors: factors that contribute to satisfaction (Motivators) and factors that contribute to dissatisfaction (Hygienists). Motivators (such as a challenging job, achievement, responsibility, advancement, recognition) cause satisfaction, but their absence does not result in dissatisfaction. On the other hand, the absence of Hygienists (such as company policy, administration, working conditions, status and benefits, wages etc.) results in dissatisfaction. Motivational factors are largely intrinsic by nature, while hygienists, according to this theory, have material nature (extrinsic) and they are under the control of the managers. Some parts of the obtained results are in favour of this theory: the nature and dynamics of the work, as well as working in a competitive international market, proved to be sources of satisfaction. On the other hand, the working conditions in our study showed to be a source of both job satisfaction and dissatisfaction, although more often relating to dissatisfaction, which also partially confirms the theory. However, in our study the financial issue was the primary source of satisfaction, which is not in accordance with the theoretical assumptions, and can be explained by the specificity of the sample living and working in a period of poor economic situation in the country. The only study to which, to some extent, we can further compare the results obtained is a Danish study [24] whose aim was to examine motivating and demotivating factors for staying in the profession. The results of the Danish study showed that psychosocial factors are more important than organisational, i.e. the main motivators were length of stay at home, level of responsibility, and level of challenge, while the main demotivators were separation from home and family, human-resource management, and regulatory requirements.

Possible limitations of the study results are related to the use of survey method since Internet samples may be biased in favour of more educated and wealthy individuals. However, this selectivity is being diminished with nowadays growth of Internet connectivity. Yet, key threats to the validity of data largely stem from the fact that researchers cannot control the identity and truthfulness of participants. However, comparisons with traditional survey methods show that the data collected using Internet methods are not as flawed as is commonly believed, i.e. data provided by online surveys are of at least as good quality as those provided by traditional paper-and-pencil methods. Namely, results obtained by Internet surveys generalise across presentation formats, do not appear to be tainted by false data or repeat responders, and are, so far, consistent with results from traditional methods $[25,26]$.

The main disadvantage of the presented results is the limited generalisability which stems from sample's questionable representativeness of the population of Croatian seafarers on cargo ships. Therefore, they should be verified in further studies based on representative samples, taking into account different socio-demographic and work characteristics which may moderate job satisfaction level. Obtained results of different factors which determine job (dis)satisfaction in seafarers, however, may present a good start point for construction of job satisfaction measurement tools in this particular occupation.

\section{CONCLUSIONS}

The results show a moderate level of job satisfaction in the tested sample of Croatian seafarers on cargo ships. The highest level of satisfaction relates to salary, while the lowest levels of satisfaction relate to the realisation of benefits and work organisation on board. The most common sources of job satisfaction are financial stability and security, relationship of work to days off and quality of free days, and the nature and pace of the work. On the other hand, the most common sources of job dissatisfaction relate to living and working conditions on board, the status of seafarers in Croatia, and separation from home and family.

\section{ACKNOWLEDGEMENTS}

Since the study was carried out without financial support, we sincerely thank to all subjects which participated in the study and to all organisations which helped us with sampling. 


\section{REFERENCES}

1. Carotenuto A, Molino I, Fasanaro AM, Amenta F. Psychological stress in seafarers: a review. Int Marit Health 2012; 63:188-194.

2. Oldenburg M, Baur X, Schlaich C. Occupational risks and challenges of seafaring. J Occup Health 2010; 52: 249-256. doi:10.1539/ joh.k10004.

3. Allen $\mathrm{P}$, Wadsworth $\mathrm{E}$, Smith A. Seafarers' fatigue: a review of the recent literature. Int Marit Health 2008; 59: 81-92.

4. Iversen, RTB. The mental health of seafarers. Int Marit Health 2012; 63: 78-89.

5. MacLachlan M, Kavanagh B, Kay A. Maritime health: a review with suggestions for research. Int Marit Health 2012; 63: 1-6.

6. Hansen HL, Nielsen D, Frydenberg M. Occupational accidents aboard merchant ships. Occup Environ Med 2002; 59: 85-91. doi:10.1136/oem.59.2.85.

7. Roberts SE, Marlow PB. Traumatic work related mortality among seafarers employed in British merchant shipping, 1976-2002. Occup Environ Med 2005; 62: 172-180. doi:10.1136/ oem.2003.012377.

8. Roberts SE. Fatal work-related accidents in UK merchant shipping from 1919 to 2005. Occup Med 2008; 58: 129-137. doi:10.1093/ occmed/kqm149.

9. Roberts SE. Work related mortality from gastrointestinal diseases and alcohol among seafarers employed in British merchant shipping from 1939 to 2002. Int Marit Health 2005; 56: 29-47.

10. Roberts SE, Jaremin B. Cardiovascular disease mortality in British merchant shipping and among British seafarers ashore in Britain. Int Marit Health 2010; 61: 107-16.

11. Roberts SE, Jaremin B, Chalasani P, Rodgers SE. Suicides among seafarers in UK merchant shipping, 1919-2005. Occup Med 2010; 60: 54-61. doi:10.1093/occmed/kqp133.

12. Szymanska K, Jaremin B, Rosik E. Suicides among Polish seamen and fishermen during work at sea. Int Marit Health 2006; 57 : 36-45.

13. Ministry of Maritime Affairs, Transport and Infrastructure [Ministarstvo pomorstva, prometa i infrastrukture] Strategy for Maritime Development and Integrated Maritime Policy of the Republic of Croatia, 2014-2020 [Strategija pomorskog razvitka i integralne pomorske politike Republike Hrvatske za razdoblje od 2014. do 2020. godine]. http://www.mppi.hr/.
14. Locke EA. The nature and causes of job satisfaction. In: Dunnette MD ed. Handbook of industrial and organizational psychology. Rand McNally, Chicago1976, pp. 1297-1349.

15. Faragher EB, Cass M, Cooper CL. The relationship between job satisfaction and health: a meta-analysis. Occup Environ Med 2005; 62: 105-112. doi:10.1136/oem.2002.006734.

16. Saari LM, Judge TA. Employee attitudes and job satisfaction. Hum Res Manage 2004; 43: 395-407. doi:10.1002/hrm.20032.

17. Penezić Z, Slišković A, Kevrić D. Some correlates of life satisfaction in seamen [Neki korelati zadovoljstva životom kod pomoraca]. Contemp Psychol [Suvremena psihologija] 2013; 16: 83-92.

18. Nielsen MB, Bergheim K, Eid J. Relationships between work environment factors and workers' well-being in the maritime industry. Int Marit Health 2013; 64: 80-88.

19. Jensen OC, Sørensen JFL, Thomas M, Canals ML, Nikolic N, Hu Y. Working conditions in international seafaring. Occup Med 2006; 56: 393-397. doi:10.1093/occmed/kql038.

20. Judge TA, Parker SK, Colbert AE, Heller D, llies R. Job satisfaction: a cross-cultural review. In: Anderson N, Ones DS, Sinangil HK, Viswesvaran C eds. Handbook of industrial, work, and organizational psychology. Sage, London, UK 2001, pp. 25-52.

21. Judge TA, llies R. Affect and job satisfaction: a study of their relationship at work and at home. J Appl Psy 2004; 89: 661-673. doi:10.1037/0021-9010.89.4.661.

22. Measuring job satisfaction in surveys: comparative analytical report. European Foundation for the Improvement of Living and Working Conditions, 2007. http://www.eurofound.europa.eu/.

23. Stello CM. Herzberg's Two-factor theory of job satisfaction: an integrative literature review. Department of Organizational Leadership, Policy, and Development, Minnesota 2011.

24. Haka M, Borch DF, Jensen C, Leppin A. Should I stay or should I go? Motivational profiles of Danish seafaring officers and non-officers. Int Marit Health 2011; 62: 20-30.

25. Gosling SD, Vazire S, Srivastava S, John OP. Should we trust Web-based studies? A comparative analysis of six preconceptions about Internet questionnaires. Am Psychol 2004; 59: 93-104. doi:10.1037/0003-066x.59.2.93.

26. Gosling SD, Mason W. Internet research in psychology. Ann Rev Psychol 2015; 66: 877-902. doi:10.1146/annurev-psych$-010814-015321$. 


\section{APPENDIX}

\section{OVERALL JOB SATISFACTION}

Please answer as honestly as you can how strongly you agree or disagree with each of items. With each statement, check the appropriate number. Numbers have the following meanings:

1 = strongly disagree; 2 = disagree; 3 = neither agree nor disagree; 4 = agree; 5 = strongly agree.

$\begin{array}{llllll}\text { I feel fairly satisfied with my present job. } & 1 & 2 & 3 & 4 & 5 \\ \text { Most of my days I am enthusiastic about my work. } & 1 & 2 & 3 & 4 & 5 \\ \text { Each day at work seems like it will never end*. } & 1 & 2 & 3 & 4 & 5 \\ \text { I find real enjoyment in my work. } & 1 & 2 & 3 & 4 & 5\end{array}$

*Recoded items

\section{SATISFACTION BY DIFFERENT JOB ASPECTS}

How satisfied are you with following job dimensions?

1 = not at all satisfied; 2 = not satisfied; 3 = neither satisfied nor dissatisfied; 4 = satisfied; 5 = completely satisfied.

\begin{tabular}{|c|c|c|c|c|c|}
\hline Salary & 1 & 2 & 3 & 4 & 5 \\
\hline Realisation of benefits & 1 & 2 & 3 & 4 & 5 \\
\hline Working conditions on board & 1 & 2 & 3 & 4 & 5 \\
\hline Organisation of work on board & 1 & 2 & 3 & 4 & 5 \\
\hline Organisation of work in the company & 1 & 2 & 3 & 4 & 5 \\
\hline Superiors & 1 & 2 & 3 & 4 & 5 \\
\hline Opportunities for spending leisure time on board & 1 & 2 & 3 & 4 & 5 \\
\hline Food & 1 & 2 & 3 & 4 & 5 \\
\hline Interpersonal relations on board & 1 & 2 & 3 & 4 & 5 \\
\hline Progression opportunities. & 1 & 2 & 3 & 4 & 5 \\
\hline
\end{tabular}

\section{SOURCES OF JOB SATISFACTION AND JOB DISSATISFACTION}
1. With respect to your job as a seafarer, please specify what makes you particularly satisfied?
2. With respect to your job as a seafarer, please specify what makes you particularly dissatisfied? 